\title{
SENYAWA BIOAKTIF RUMPUT LAUT DAN AMPAS TEH SEBAGAI ANTIBAKTERI DALAM FORMULA MASKER WAJAH
}

\author{
Nurjanah*, Bintang Efrata Aprilia, Andika Fransiskayana, Mutiara Rahmawati, \\ Tati Nurhayati \\ Departemen Teknologi Hasil Perairan Fakultas Perikanan dan Ilmu Kelautan \\ Institut Pertanian Bogor, Kampus IPB Darmaga, Jalan Agatis, Bogor 16680 Jawa Barat \\ Telepon (0251) 8622909-8622906, Faks. (0251) 8622915 \\ ${ }^{\star}$ Korespondensi: inunthp10@gmail.com \\ Diterima: 6 Juni 2018/Disetujui: 25 Agustus 2018
}

Cara sitasi: Nurjanah, Aprilia BE, Fransiskayana A, Rahmawati M, Nurhayati T. 2018. Senyawa bioaktif rumput laut dan ampas teh sebagai antibakteri dalam formula masker wajah. Jurnal Pengolahan Hasil Perikanan Indonesia. 20(2): 304-316.

Abstrak
Jerawat merupakan penyakit kulit karena adanya sumbatan pada pori-pori kulit wajah yang disebabkan oleh penumpukan minyak yang mengakibatkan adanya aktivitas bakteri sehingga terjadi peradangan pada kulit. Pemanfaatan senyawa bioaktif pada rumput laut dan ampas teh menjadi solusi untuk menangani $P$. acnes karena memiliki sifat sebagai antibakteri. Tujuan penelitian adalah menentukan rasio bubur rumput laut Sargassum sp. dan E. cottonii terbaik dalam menghambat $P$. acnes serta mengetahui karakteristik ampas teh dalam menghambat $P$. acnes dan $S$. aureus dengan karakteristik produk masker wajah yang terbaik. Penelitian ini terdiri atas 3 perlakuan yaitu 1:1 ; 1:2 dan 2:1 untuk Sargassum sp. dan E. cottonii. Analisis untuk menentukan rasio bubur rumput laut terbaik yaitu fitokimia, viskositas, $\mathrm{pH}$, kadar air, total fenol, aktivitas antioksidan dengan metode DPPH, dan uji antibakteri. Rasio terbaik bubur rumput laut dengan

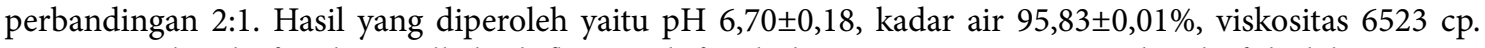
Komponen bioaktif meliputi alkaloid, flavonoid, fenol, dan saponin. Komponen bioaktif di dalam ampas teh yaitu tanin, fenol, dan steroid. Aktivitas antioksidan yaitu 145,89 $\pm 0,42 \mathrm{ppm}$ dan daya hambat terhadap $P$. acnes yaitu 3,62 $\pm 0,04 \mathrm{~mm}$, total fenol 50,43 mg GAE/g. Ampas teh memiliki kemampuan menghambat $P$. acnes $2,44 \mathrm{~mm}$ dan $S$. aureus $8,56 \mathrm{~mm}$. Analisis karakteristik produk masker yaitu daya sebar, $\mathrm{pH}$, dan antibakteri. Karakteristik produk masker wajah yang diperoleh yaitu $\mathrm{pH} 7,09 \pm 0,16$ dan daya sebar $5 \mathrm{~cm}$ serta diameter daya hambat terhadap $P$. acnes yaitu $2,60 \pm 0,00 \mathrm{~mm}$ dan terhadap $S$. aureus yaitu $10,67 \pm 0.00$ $\mathrm{mm}$. Penerimaan konsumen terhadap produk melalui uji sensori berkisar antara netral sampai suka.

Kata kunci : E. cottonii, fenol, jerawat, Propionibacterium acnes, Sargassum sp.

\section{Bioactive Compounds of Seaweed and Tea Pulp as Antibacterials in Face Mask Formula}

\begin{abstract}
Acne vulgaris is a skin disease due to blockage in the pores of the face's skin caused by oil accumulation of bacterial activity resulting in skin inflammation. The use of bioactive compounds in seaweed and tea pulp is a solution to deal with $P$. acnes bacteria because it has antibacterial properties. The purpose of this study was to determine the best ratio of seaweed slurry Sargassum sp. and E. cottonii combination in inhibiting $P$. acnes and determine the characteristics of tea pulp in inhibiting $P$. acnes and $S$. aureus for the best facial mask product. This study consisted of 3 treatments 1:1;1:2 and 2:1 for Sargassum sp. and E. cottonii ratios. Analytical methods to determine the ratio of the best seaweed slurry were: phytochemical, viscosity, $\mathrm{pH}$, moisture, total phenol, antioxidant activity and antibacterial. The results indicate that the best ratio is 2:1. The results obtained were $\mathrm{pH} 6.70 \pm 0.18$, moisture $95.83 \pm 0.01 \%$, viscosity $6523 \mathrm{cp}$. Bioactive compounds in seaweed slurry include alkaloids, flavonoids, phenols, and saponins. Bioactive compounds in ingredients added to tea pulp, namely tannins, phenols and steroids. The antioxidant activity of seaweed slurry was $145.89 \pm 0.42 \mathrm{ppm}$, the inhibitory power for $P$. acnes $3.62 \pm 0.04 \mathrm{~mm}$ and total phenol $50.43 \mathrm{mg} \mathrm{GAE} / \mathrm{g}$. Analysis of mask product characteristics from the best ratio of seaweed slurry, were dispersion, $\mathrm{pH}$, and antibacterial. Tea pulp has the ability to inhibit P.acnes by $2.44 \mathrm{~mm}$ and S. aureus by $8.56 \mathrm{~mm}$. Characteristics of facial mask obtained were $\mathrm{pH} 7.09 \pm 0.16$, dispersion power $5 \mathrm{~cm}$ and the diameter of the inhibitory power against P.acnes $2.60 \pm 0.00 \mathrm{~mm}$ and against $S$. aureus $10.67 \pm 0.00 \mathrm{~mm}$. Consumer acceptance of the product through sensory testing ranges from neutral to like.
\end{abstract}

Kata kunci : E. cottonii, fenol, jerawat, Propionibacterium acnes, Sargassum sp. 


\section{PENDAHULUAN}

Jerawat (Acne vulgaris) merupakan peradangan pada kulit wajah akibat tersumbatnya pori-pori kulit yang disebabkan oleh kelebihan sekresi kelenjar minyak (sebacea) pada kulit wajah (Achroni 2012). Vilar et al. (2015) menyatakan bahwa ada 317 responden yang memiliki masalah jerawat, $48,6 \%$ di antaranya merasa dirinya stres, $19,4 \%$ takut untuk berfoto, $22 \%$ takut bertemu seseorang untuk pertama kali, dan $8,5 \%$ takut untuk bertemu kolega. Jerawat memang tidak mengancam kehidupan, namun dapat menyebabkan masalah serius dalam kondisi psikologis dan kehidupan sosial penderita di masa depan.

Faktor terbentuknya jerawat dipengaruhi oleh jenis kulit. Kulit berminyak menjadi faktor dengan persentase terbesar yaitu 53,6\% dibandingkan pada kulit normal dan kulit kering (Kartheepan et al. 2015). Kondisi tersebut dipengaruhi oleh hormon androgen dihydrotestosterone yang meningkatkan ukuran kelenjar sebacea dan meningkatkan produksi sebum (Jones 2014). Kondisi ini menguntungkan bagi bakteri penyebab jerawat yaitu Staphylococcus aureus dan Propionibacterium acnes. Bakteri penyebab jerawat ini akan mendapatkan asupan nutrien dari sebum yang terdiri atas trigliserida dan asam lemak (Jawetz dan Adelberg's 2005). Ramdani dan Sibero (2015) menyatakan bakteri $P$. acnes dan S.aureus akan memecah trigilserida menjadi asam lemak bebas dan membentuk kolonisasi yang memicu terjadinya inflamasi pada jerawat.

Produk kosmetik masker wajah dapat menjadi salah satu cara mengatasi masalah jerawat. Masker wajah merupakan kosmetik yang digunakan untuk merawat kondisi wajah seseorang agar tetap sehat serta penggunaannya dapat mengatasi masalahmasalah kulit wajah seperti jerawat (Melayanti dan Dwiyanti 2017). Peredaran produk kosmetik berbahan kimia berbahaya yang bersifat karsinogenik saat ini marak terjadi. Tahun 2016 Badan POM menemukan 29 jenis kosmetik yang mengandung bahan kimia berbahaya yaitu merkuri, asam retinoat, dan hidrokuinon pada produk perawatan kulit (BPOM 2016). Alternatif lain yang dianggap lebih aman dalam mengatasi masalah jerawat adalah menggunakan bahan aktif alami hasil perairan di antaranya rumput laut.

Rumput laut tropika mengandung beberapa komponen bioaktif yang bermanfaat bagi kesehatan, baik berupa produk pangan maupun produk non pangan. Potensi rumput laut tropika telah banyak dilaporkan, di antaranya sebagai bahan baku kosmetik yang mengandung antioksidan (Nurjanah et al. 2016; Nurjanah et al, 2017; Luthfiyana at al. 2017; Maharany et al. 2017; Yanuarti et al. 2017; Dolorosa et al. 2017) serta sebagai bahan baku pembuatan garam (Diachanti et al. 2017; Nufus et al. 2017). Termasuk rumput laut sebagai sumber serat (Nurjanah et al. 2018) serta penggunaan kombinasi rumput laut merah dan coklat sebagai tabir surya (Nurjanah et al. 2017).

Rumput laut merupakan salah satu hasil perairan yang banyak mengandung senyawa bioaktif yang dapat dimanfaatkan di bidang kosmetika yang berfungsi sebagai antioksidan dan antibakteri.Sedjatietal.(2017) melaporkan bahwa fenol pada ekstrak Sargassum sp. berfungsi sebagai antioksidan dengan $\mathrm{IC}_{50}$ yaitu 1,36 mgGAE/g. Fenol, saponin, dan flavonoid pada Sargassum sp. juga memiliki aktivitas antibakteri, dengan diameter daya hambat terhadap bakteri S. aureus 6,323 mm (Pangestuti et al. 2017). Diachanty et al. (2017) menyatakan bahwa ekstrak Sargassum polycystum mengandung flavonoid dan steroid yang berfungsi sebagai antioksidan dengan nilai $\mathrm{IC}_{50}$ sebesar $3,4 \mathrm{mg} / \mathrm{L}$. Senyawa bioaktif flavonoid pada ekstrak $E$. cottonii berfungsi sebagai antibakteri, diameter daya hambat yang mampu dihasilkan terhadap Staphylococcus sp. yaitu 17,33 mm dan E. coli $16,33 \mathrm{~mm}$. Nilai zona hambat ini dikategorikan dalam kategori kuat (Sartika et al. 2013).

Ampas teh merupakan salah satu bahan alami yang mengandung senyawa bioaktif yang bermanfaat dalam berbagai bidang. Pemanfaatan limbah ampas teh yang sudah dilakukan saat ini meliputi pengaruhnya dalam media pertumbuhan beberapa tanaman (Pangihutan et al. 2017) dan pemanfaatannya dalam ransum kelinci (Wibowo et al. 2014). Ampas teh berdasarkan pengalaman empiris mempunyai banyak 
khasiat yang bermanfaat bagi kesehatan kulit wajah. Teh memiliki senyawa bioaktif yaitu tanin dan polifenol yang berfungsi sebagai antioksidan (Kusumaningrum et al. 2013). Senyawa antioksidan berperan dalam menetralisir radikal bebas sehingga dapat menghambat penuaan dini. Ampas teh juga memiliki aktivitas antibakteri Staphylococcus epidermidis dengan diameter daya hambat yang dihasilkan sebesar 6,03 $\mathrm{mm}$ (Widiati 2011). Kandungan polifenol pada ampas teh dapat menghambat pembentukan lemak dari asam lemak sehingga mencegah kandungan minyak berlebih.

Penggunaan masker wajah berbahan dasar alami dapat menjadi alternatif untuk mengganti masker berbahan kimia untuk pengobatan jerawat karena tidak memiliki efek jangka panjang yang berbahaya. Penggunaan bahan-bahan alami sebagai bahan baku masker wajah sudah banyak dilakukan, namun pemanfaatan dari dua jenis rumput laut dalam bentuk bubur rumput laut Sargassum sp. dan E. cottonii serta bahan tambahan ampas teh sebagai bahan baku masker wajah belum dilakukan. Tujuan penelitian adalah menentukan rasio bubur rumput laut Sargassum sp. dan E. cottonii terbaik dalam menghambat $P$. acnes serta mengetahui karakteristik ampas teh dalam menghambat $P$. acnes dan $S$. aureus dengan karakteristik produk masker wajah yang terbaik

\section{BAHAN DAN METODE Bahan dan Alat}

Bahan yang digunakan adalah rumput laut cokelat Sargassum sp. yang berasal dari pantai Lhok Bubon Aceh, rumput laut merah E. cottonii yang diambil dari Banten, dan bubuk ampas teh merk "Nyapu" yang berasal dari limbah rumah tangga. Bahan-Bahan yang digunakan untuk analisis terdiri atas air demineralisasi, buffer 4, buffer 7, reagen Meyer, Dragendorff, Wagner, $\mathrm{H}_{2} \mathrm{SO}_{4}$, serbuk Mg (Merck), amil alkohol, alkohol, etanol, $\mathrm{FeCl}_{3} \%$ (Merck), $\mathrm{HCl} 2 \mathrm{~N}, \mathrm{FeCl}_{3} 1 \%$ (Merck), anhidra asam asetat, kloroform, etanol 96\%, DPPH, asam askorbat (Merck), blood agar, Mueller Hinton Agar (MHA) bakteri P. acnes, S. aureus akuades, asam galat (Merck), Folin- ciocalteu (Merck), $\quad \mathrm{Na}_{2} \mathrm{CO}_{3}$. Bahan-bahan yang digunakan untuk membuat masker yaitu air, gliserin, TEA, nipasol, asam stearat, setil alkohol, nipagin, fragrance. Alat yang digunakan antara lain alat-alat gelas (Pyrex), oven, desikator, $\mathrm{pH}$ meter, kompor listrik, alat timbang, alumunium foil, vortex (VM-300), inkubator, spektrofotometer UV-Vis OPTIMA SP-300, termometer, pipet volumetrik, mikropipet (Gilson), viscometer, cawan petri, spiritus, dan ose steril.

\section{Metode Penelitian \\ Preparasi bubur rumput laut}

Pembuatan bubur rumput laut mengacu pada penelitian Luthfiyana et al. (2016) yang dimodifikasi. Rumput laut E. cottonii dan Sargassum sp. dicuci hingga bersih dan direndam di dalam air demineralisasi selama 12 jam dengan rasio 1:20. Rumput laut kemudian dibilas agar sisa-sisa kotoran yang masih menempel hilang. Pembuatan bubur rumput laut dilakukan dengan mencampurkan rumput laut dan air demineralisasi dengan perbandingan 1:1 untuk E. cottonii dan 1:1,5 untuk Sargassum sp. kemudian dihomogenisasi dengan blender selama 3-5 menit.

\section{Preparasi ampas teh}

Ampas teh ditiriskan/diperas untuk membuang sisa-sisa air teh, setelah itu disimpan di dalam wadah bersih dan dimasukkan ke dalam kulkas. Penyimpanan ini bertujuan agar air yang masih terkandung dalam ampas teh akan menguap. Ampas teh yang sudah kering, kemudian dihaluskan menggunakan blender.

\section{Pembuatan masker wajah}

Pembuatan masker wajah mengacu pada penelitian Fachrozan (2017) dengan beberapa modifikasi. Bubur rumput laut dan bubuk ampas teh dicampur dan diaduk hingga rata. Bahan-bahan tambahan yang digunakan meliputi bahan yang larut dalam minyak di antaranya setil alkohol, asam stearat, dan nipagin. Bahan yang larut dalam air antara lain gliserin, TEA, air, dan nipasol, serta bahan yang larut dalam minyak dicampur hingga homogen pada suhu $\pm 75^{\circ} \mathrm{C}$ disebut 
fase minyak. Bahan yang larut dalam air dicampur hingga homogen pada suhu $\pm 75^{\circ} \mathrm{C}$ disebut fase air. Fase air yang telah terbentuk dimasukkan ke dalam fase minyak, diaduk hingga suhu menjadi $\pm 40^{\circ} \mathrm{C}$ dan terbentuk basis masker yang homogen. Bubur rumput laut dan ampas teh kemudian dimasukkan ke dalam basis masker dan diaduk hingga homogen, selanjutnya masker wajah dikemas ke dalam wadah.

\section{Prosedur analisis}

Penelitian ini menggunakan rancangan acak lengkap (RAL) yang terdiri atas 3 perlakuan dengan dua kali ulangan. Perlakuan dalam penelitian ini yaitu rasio bubur rumput laut Sargassum sp. dan E. cottonii pada perbandingan $1: 1 ; 1: 2$ dan 2:1. Rasio terbaik digunakan sebagai bahan baku pembuatan masker wajah. Analisis yang dilakukan meliputi analisis fitokimia yang mengacu pada Harbone (1987),terdiri dari analisis alkaloid, flavonoid, fenol hidrokuinon, steroid/triterpenoid, tanin, dan saponin. Analisis viskositas berdasarkan metode AOAC (1995) diukur menggunakan Viscometer Brookfield. Sampel sebanyak 30 gram diukur viskositasnya menggunakan Viscometer TV10 , diukur menggunakan spindel no. 4 dengan kecepatan $60 \mathrm{rpm}$.

Analisis kadar air mengacu pada SNI (1992). Uji total fenol mengacu pada Ramamoorthy dan Bono (2007). Sampel sebanyak $5 \mathrm{mg}$ dilarutkan dalam $5 \mathrm{~mL}$ air demineralisai. Hasil pengenceran sampel diambil sebanyak $1 \mathrm{~mL}$, kemudian ditambahkan $1 \mathrm{~mL}$ etanol $96 \%, 5 \mathrm{~mL}$ akuades dan $0,5 \mathrm{~mL}$ reagen Folin Ciocalteau 50\%. Campuran didiamkan selama 5 menit dan ditambahkan $1 \mathrm{~mL} \mathrm{Na} \mathrm{CO}_{3}$ 5\%. Campuran dihomogenkan lalu diinkubasi dalam kondisi gelap selama satu jam. Absorbansi diukur dengan spektrofotometer UV-Vis pada panjang gelombang $725 \mathrm{~nm}$.

Analisis aktivitas antioksidan menggunakan metode DPPH (1,1-difenil-2pikrilhidrazil) mengacu pada Molyneux (2004). Uji aktivitas antioksidan terdiri atas pembuatan stok DPPH 0,001 M dan pembuatan larutan stok sampel dengan konsentrasi 50 ppm sampai 250 ppm. Absorbansi sampel diukur dengan spektrofotometer UV-Visible pada panjang gelombang $517 \mathrm{~nm}$. Persamaan regresi diperoleh dari hubungan antara konsentrasi sampel dan presentase penghambatan aktivitas radikal bebas. Nilai $\mathrm{IC}_{50}$ dihitung dengan menggunakan persamaan regresi linier. Analisis $\mathrm{pH}$ mengacu pada metode Hamsinah et al. (2016), Pengukuran dilakukan dengan cara mencelupkan elektroda $\mathrm{pH}$ ke dalam setiap batch sampel. Uji antibakteri mengacu pada metode Marselia et al. (2015) menggunakan bakteri P.acnes dan S. aureus. Bakteri P. acnes disebarkan merata pada media blood agar dan bakteri S.aureus pada media MHA dengan menggunakan cotton bud. Kedua media kemudian dibuat sumur. Tiap sumur diberikan sampel antibakteri hingga rata. Kontrol positif yang digunakan yaitu clindamycin dan kontrol negatif yaitu akuades steril. Inkubasi selama 24 jam pada suhu $37^{\circ} \mathrm{C}$ dalam kondisi anaerob untuk media MHA. Diameter zona hambat diukur pada daerah bening sumur menggunakan jangka sorong.

Uji daya sebar mengacu pada Djajadisastra (2004). Sediaan gel yang telah terbentuk ditimbang sebanyak 1 gram kemudian diletakkan di atas kaca berukuran $30 \times 40 \mathrm{~cm}$, selanjutnya ditutup dengan mika dan diberikan pemberat, setelah 1 menit kemudian diameter yang terbentuk diukur menggunakan jangka sorong. Uji sensori terhadap masker wajah bersifat subjektif yang dilakukan oleh 30 orang panelis dari mahasiswi Teknologi Hasil Perairan IPB. Skala hedonik yang digunakan berkisar 1-5, (1) sangat tidak suka; (2) tidak suka; (3) netral; (4) suka; (5) sangat suka. Parameter pengujian yang dilakukan meliputi tampilan, warna, aroma, dan tekstur. Data yang diperoleh diuji dengan uji statistik non parametrik Kruskal Wallis dan hasil uji jika memberikan pengaruh nyata, maka dilanjutkan dengan uji Duncan.

\section{HASIL DAN PEMBAHASAN Kadar air}

Kadar air yang diperoleh dari perbandingan Sargassum sp. dan E. cottonii $(1: 1 ; 1: 2 ; 2: 1)$ secara berturut-turut yaitu $96,07 \%, 96,34 \%, 95,83 \%$. Hasil kadar air untuk ketiga perlakuan dapat dilihat pada Gambar 1. 
Perlakuan kombinasi rumput laut memberikan hasil yang berbeda nyata terhadap kadar air yang dihasilkan $(\mathrm{P}<0,05)$. Kadar air bahan baku bubur Sargassum sp. dan E. cottonii pada penelitian ini tergolong sangat tinggi, karena praperlakuan perendaman rumput laut kering dan penambahan air demineralisasi pada saat pembuatan bubur rumput laut. Hasil perendaman ini menunjukkan kemampuan rehidrasi rumput laut mencapai 4 kali dari berat awal, yaitu rumput laut kering $100 \mathrm{~g}$ setelah perendaman memiliki berat $424 \mathrm{~g}$.

Ihsan (2016) melaporkan bahwa kadar air bubur rumput laut E. cottonii yaitu 95,95\%. Dolorosa et al. (2017) menambahkan bahwa E. cottonii memiliki kadar air yang lebih tinggi dibandingkan dengan Sargassum plagyophyllum. Perbedaan ini dipengaruhi oleh spesies dan umur panen yang berbeda. Hal ini sesuai dengan hasil penelitian yaitu perlakuan dengan jumlah E. cottonii lebih banyak memiliki kadar air yang paling tinggi.

Rumput laut E. cottonii merupakan jenis rumput laut merah penghasil karaginan. Karaginan merupakan polisakarida yang tersusun atas polimer sulfat bersifat hidrofilik yang dapat mengikat air. Semakin banyak jumlah karaginan yang ditambahkan maka semakin tinggi kadar air yang dihasilkan (Putra et al. 2015).

\section{Nilai $\mathrm{pH}$}

Analisis $\mathrm{pH}$ dilakukan untuk menentukan tingkat keasaman pada bubur rumput laut. Hasil analisis $\mathrm{pH}$ bahan baku bubur rumput laut untuk masing-masing perlakuan dapat dilihat pada Gambar 2.

Perlakuan kombinasi rumput laut memberikan hasil yang berbeda nyata terhadap nilai $\mathrm{pH}$ rasio bubur rumput laut 1:1 dan 2:1 yang dihasilkan $(\mathrm{P}<0,05)$. Hasil analisis $\mathrm{pH}$ pada perbandingan $1: 1 ; 1: 2$ dan $2: 1$ secara berturut-turut yaitu 6,$09 ; 6,30$; dan 6,70. Hasil analisis $\mathrm{pH}$ bubur menunjukkan bahwa semua perlakuan rasio bubur rumput laut ini aman digunakan sebagai bahan baku masker wajah karena memiliki nilai $\mathrm{pH}$ yang sesuai dengan standar yang ditetapkan SNI 16-6070-1999 yaitu berkisar antara 4,5-8,0.

\section{Viskositas}

Uji viskositas bertujuan untuk mengetahui tingkat kekentalan pada bubur rumput laut. Hasil uji viskositas untuk masing-masing perlakuan dapat dilihat pada Gambar 3.

Perlakuan kombinasi rumput laut memberikan hasil yang berbeda nyata terhadap nilai viskositas yang dihasilkan $(\mathrm{P}<0,05)$. Hasil uji viskositas pada perbandingan 1:1; 1:2 dan 2:1 secara berturut-turut yaitu $9537 \mathrm{cp}, 10000$ cp, dan 6523 cp. Hasil tersebut menunjukkan bahwa jumlah E. cottonii yang di tambahkan berpengaruh terhadap viskositas yang tinggi.

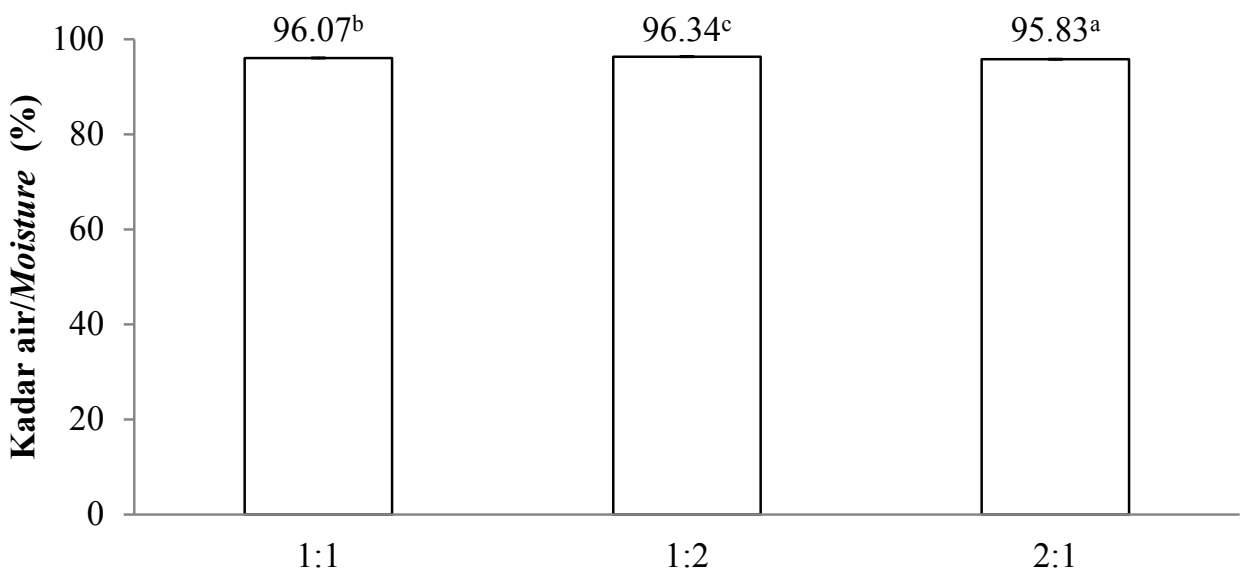

Rasio Sargassum sp. dan E. cottonii/ Ratio of Sargassum sp. and E. cottonii

Gambar 1 Kadar air bubur Sargassum sp. dan E. cottonii

(Figure 1 Moisture content of Sargassum sp. dan E. cottonii porridge) 


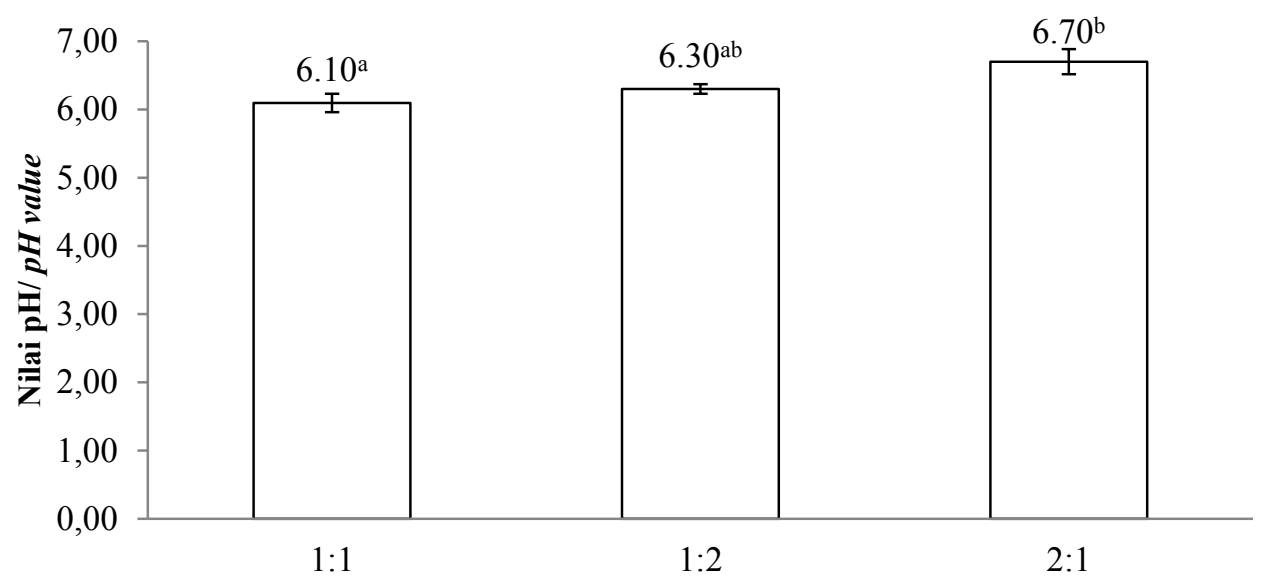

Rasio Sargassum sp. dan E. cottonii/ Ratio of Sargassum sp. and E. cottonii

Gambar 2 Nilai pH bubur Sargassum sp. dan E. cottonii

(Figure 2 pH value of Sargassum sp. dan E. cottonii porridge)

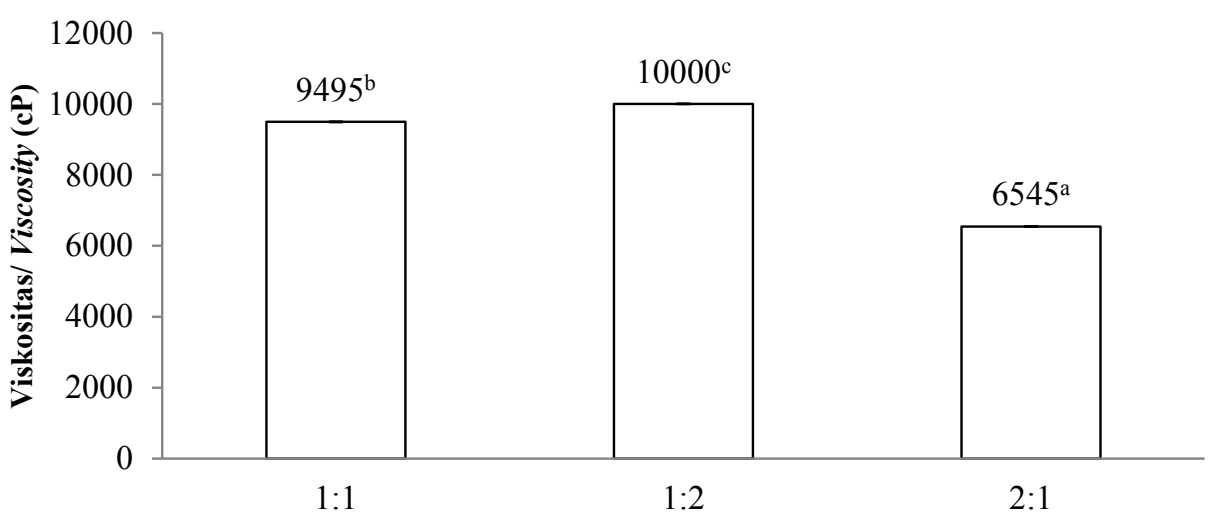

Rasio Sargassum sp. dan E. cottonii/ Ratio of Sargassum sp. and E. cottonii

Gambar 3 Viskositas bubur Sargassum sp. dan E. cottonii

(Figure 3 Viscosity of Sargassum sp. and E. cottonii porridge)

Hal ini karena E. cottonii merupakan salah satu jenis rumput laut yang menghasilkan karaginan. Viskositas bahan baku akan mempengaruhi tekstur dari produk masker.

Karaginan merupakan senyawa polisakarida yang tersusun atas unit $\beta$-D-galaktosa dan $\alpha$-L-galaktosa 3,6 anhidrogalaktosa yang dihubungkan dengan 1,4 glikosidika, dengan setiap unit galaktosa mengikat gugus sulfat (Pebrianata 2005). Gugus sulfat tersebut menyebabkan terjadinya gaya tolak menolak antara yang bermuatan negatif sehingga rantai polimer kaku dan tertarik kencang mengakibatkan viskositas meningkat, selain itu sifat hidrofilik molekul tersebut menyebabkan rantai polimer dikelilingi oleh lapisan molekul air yang tidak bergerak sehingga karaginan dapat meningkatkan kekentalan bahan (Diharmi et al. 2011). E. cottonii banyak digunakan pada berbagai macam produk non pangan seperti dalam formulasi kosmetik. Penelitian terkait yang sudah dilakukan yaitu E. cottonii sebagai bahan baku krim tabir surya (Luthfiyana et al. 2016; Maharany et al. 2017), sebagai bahan baku krim pencerah kulit (Dolorosa et al. 2017).

\section{Fitokimia}

Uji fitokimia dilakukan untuk mengetahui senyawa aktif (metabolit sekunder) yang terdapat di dalam bahan. Metabolit sekunder pada suatu bahan baku dapat memberikan efek fisiologis 
yang berguna bagi tubuh manusia. Analisis fitokimia dilakukan secara kualitatif untuk menentukan metabolit sekunder yang berperan sebagai antibakteri pada bakteri penyebab jerawat $P$. acnes. Hasil uji fitokimia untuk masing-masing perlakuan dapat dilihat pada Tabel 1.

Tabel 1 menunjukkan bahwa perlakuan kombinasi sediaan bubur Sargassum sp. dan E. cottonii 1:1 memiliki hasil positif pada alkaloid (Wagner), flavonoid, dan fenol. Hasil positif pada perlakuan 1:2 dan 2:1 sama yaitu pada alkaloid (wagner), flavonoid, fenol, dan saponin. Dolorosa et al. (2017) menyatakan bahwa bubur rumput laut E.cottonii positif mengandung senyawa bioaktif alkaloid dan terpenoid, sedangkan bubur rumput laut Sargassum plagyophyllum mengandung senyawa bioaktif alkaloid, steroid, flavonoid, saponin, dan tanin. Hasil ini jika dibandingkan dengan ekstrak E. cottonii yang dilakukan oleh Maharany et al. (2017) terdapat perbedaan, yaitu di dalam ekstrak E. cottonii mengandung senyawa bioaktif triterpenoid. Ekstrak Sargassum sp. mengandung flavonoid, fenol, tanin, dan saponin (Pangestuti et al. 2017)

Ampas teh dalam penelitian ini positif pada tanin dan fenol. Tanin merupakan salah satu senyawa bioaktif yang memiliki aktivitas antibakteri. Tanin akan mengganggu pertumbuhan bakteri dengan cara menginaktivasi enzim dan protein transpor pada membran sel (Rahmi et al. 2015).

\section{Aktivitas Antioksidan}

Perlakuan kombinasi rumput laut memberikan hasil yang berbeda nyata terhadap aktivitas antioksidan yang dihasilkan $(\mathrm{P}<0,05)$. Hasil analisis aktivitas antioksidan dapat dilihat pada Gambar 4. Hasil pengujian aktivitas antioksidan tertinggi terdapat pada perlakuan 2:1 yaitu 145,89 ppm. Perlakuan dengan jumlah $E$. cottonii paling banyak memiliki aktivitas antioksidan paling lemah. Hasil ini sejalan dengan penelitian Luthfiyana etal. (2016), pada bubur rumput laut Sargassum sp. memiliki aktivitas antioksidan yang lebih tinggi yaitu 119,66 ppm dibandingkan dengan bubur rumput laut E. cottonii yaitu 127,23 ppm.

Antioksidan merupakan zat yang dapat menetralisir radikal bebas sehingga atom radikal bebas yang bersifat reaktif karena tidak memilki pasangan elektron dapat mendapatkan pasangan elektron. Radikal bebas merupakan molekul yang bertanggung jawab terhadap penyakit seperti penuaan dini (Kosasih et al. 2004). Aktivitas antioksidan pada sediaan bubur Sargassum sp. dan E. cottonii yang dihasilkan tergolong sedang hingga lemah. Molyneux (2004) menyatakan suatu senyawa dikatakan memiliki aktivitas antioksidan sangat tinggi jika nilai $\mathrm{IC}_{50}<50$ $\mu \mathrm{g} / \mathrm{mL}$, kuat jika nilai $\mathrm{IC}_{50}$ berkisar pada 50 $100 \mu \mathrm{g} / \mathrm{mL}$, sedang jika nilai IC $_{50}$ berkisar pada $101-150 \mu \mathrm{g} / \mathrm{mL}$, dan lemah jika jika nilai $\mathrm{IC}_{50}>150 \mu \mathrm{g} / \mathrm{mL}$. Nilai $\mathrm{IC}_{50}$ yang rendah

Tabel 1 Hasil fitokimia sediaan bubur Sargassum sp. dan Eucheuma cottonii

Table 1 Phytochemical compounds of Sargassum sp. and E. cottonii porridge

\begin{tabular}{llll}
\hline $\begin{array}{c}\text { Uji Fitokimia/ } \\
\begin{array}{c}\text { Phytochemical } \\
\text { compounds }\end{array}\end{array}$ & \multicolumn{3}{c}{$\begin{array}{c}\text { Rasio bubur Sargassum sp. dan Eucheuma cottonii/ } \\
\text { Ratio of Sargassum sp. and E. cottonii porridge }\end{array}$} \\
\cline { 2 - 4 } & $1: 1$ & $1: 2$ & $2: 1$ \\
\hline Alkaloid & & & + \\
\hline$\bullet \quad$ Wagner & + & + & - \\
\hline$\bullet \quad$ Dragendorff & - & - & - \\
\hline$\bullet \quad$ Meyer & - & - & + \\
\hline Flavonoid & + & + & + \\
\hline Fenol & + & + & + \\
\hline Saponin & - & + & - \\
\hline Tanin & - & - & - \\
\hline Steroid & - & - & - \\
\hline Triterpenoid & - & - & \\
\hline \hline
\end{tabular}


menunjukkan kemampuan yang kuat dari suatu sampel untuk berperan sebagai donor atom hidrogen artinya bahwa sampel tersebut memiliki aktivitas antioksidan yang kuat (Diachanty et al. 2017).

Aktivitas antioksidan pada suatu sampel berhubungan dengan kandungan senyawa bioaktif yang dimiliki sampel tersebut. Senyawa polifenol terdapat pada rumput laut cokelat. Senyawa bioaktif polifenol memiliki lebih dari satu kelompok hidroksi fenol yang berikatan dengan satu atau lebih cincin aromatik. Cincin aromatik ini mempengaruhi kestabilan ikatan atom oksigen dengan atom hidrogen pada kelompok hidroksil. Sifat ini yang menyebabkan golongan polifenol sebagai salah satu senyawa yang berfungsi sebagai antioksidan (Nawaly et al. 2013).

\section{Total Fenol dan Antibakteri}

Perlakuan kombinasi rumput laut memberikan hasil yang berbeda nyata terhadap total fenol yang dihasilkan $(\mathrm{P}<0,05)$. Hasil pengujian total fenol dan antibakteri sediaan bubur Sargassum sp. dan E. cottonii disajikan pada Tabel 2 .

Tota fenol perlakuan bubur rumput laut $1: 1 ; 1: 2$ dan 2:1 yaitu 853,5 mg GAE/g, 626 mg GAE/g dan $971 \mathrm{mg} \mathrm{GAE/g.} \mathrm{Nilai} \mathrm{total}$ fenol tertinggi terdapat pada bubur rumput laut perbandingan 2:1 yaitu $971 \mathrm{mg} \mathrm{GAE} / \mathrm{g}$. Yanuarti et al. (2017) melaporkan bahwa total fenolik ekstrak E. cottonii sebesar 141,00 mg GAE/g, ekstrak Sargassum sp. yaitu 8287,18 mg GAE/g (Diachanty et al. 2017).
Aktivitas antibakteri perlakuan $1: 1 ; 1: 2$ dan 2:1 antara lain 3,24 mm, 2,75 mm 3,62 $\mathrm{mm}$. Aktivitas antibakteri menunjukkan bahwa bubur rumput laut terbukti dapat menghambat pertumbuhan bakteri $P$. acnes dengan terbentuknya zona bening di sekeliling sumur. Garg et al. (2002) menyatakan bahwa tingkat penghambatan terhadap pertumbuhan bakteri jika zona hambat $5 \mathrm{~mm}$ atau kurang maka dikategorikan lemah, 5-10 mm sedang, 10-19 mm kuat, dan $20 \mathrm{~mm}$ atau lebih dikategorikan sangat kuat. Bubur rumput laut untuk ketiga perlakuan memiliki tingkat penghambatan terhadap $P$. acnes termasuk kategori lemah.

Diameter zona hambat ampas teh pada bakteri $P$. acnes yaitu $2,44 \mathrm{~mm}$, sedangkan pada bakteri $S$. aureus yaitu sebesar $8,56 \mathrm{~mm}$. Ampas teh memiliki tingkat penghambatan yang lemah terhadap bakteri P. acnes, namun memiliki tingkat penghambatan yang sedang pada bakteri $S$. aureus.

Fenol merupakan salah satu metabolit sekunder yang berperan sebagai antibakteri. Mekanisme antibakteri senyawa fenol yaitu dengan mendenaturasi protein sel bakteri. Ikatan hidrogen yang terjadi antara senyawa fenol dengan protein pada sel menyebabkan struktur protein rusak. Ikatan hidrogen ini mempengaruhi permeabilitas dinding sel bakteri dan membran sitoplasma, karena keduanya tersusun atas protein. Terganggunya permeabilitas dinding sel dan membran sitoplasma akan menyebabkan tidak seimbangnya makromolekul dan ion yang

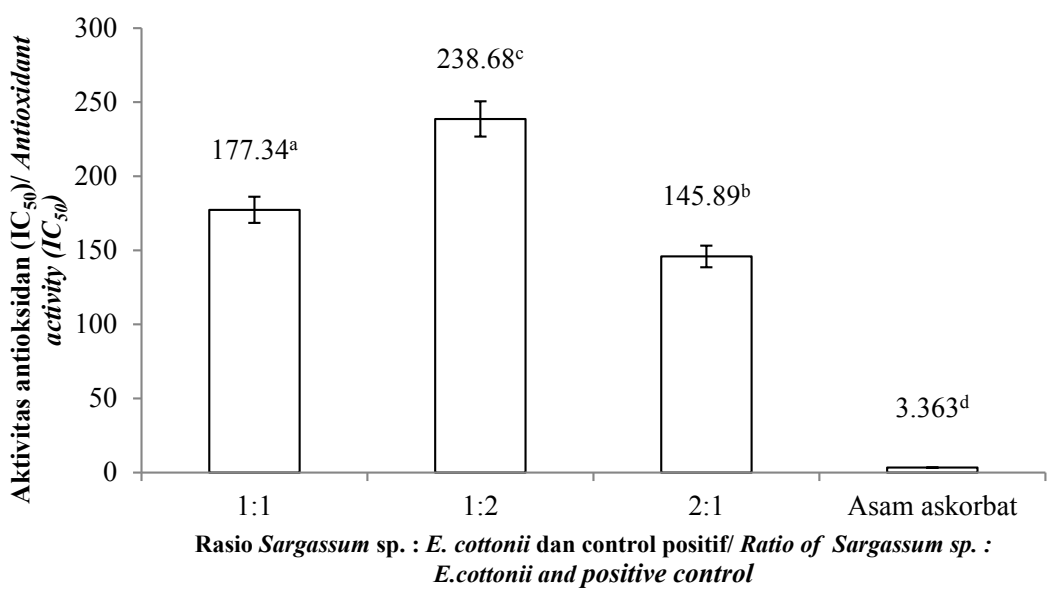

Gambar 4 Nilai IC I0 $_{50}$ bubur Sargassum sp. dan E. cottonii (Figure $4 I_{50}$ of Sargassum sp. dan E. cottonii porridge) 
ada pada sel bakteri, sehingga sel menjadi lisis (Carolia dan Noventi 2016).

Terbentuknya zona hambat diduga karena adanya senyawa antibakteri pada bubur rumput laut. Senyawa tersebut antara lain flavonoid dan fenolik. Flavonoid dianggap sebagai antibakteri karena kemampuannya dalam membentuk senyawa kompleks dengan protein sehingga dapat merusak membran sel bakteri yang dapat berakibat pada keluarnya makromolekul dan ion dari sel sehingga sel rusak dan terjadi kematian sel (Rahmi et al. 2015).

Rasio bubur rumput laut yang terpilih yaitu perbandingan 2:1. Rasio terbaik ini kemudian menjadi bahan baku acne face mask dengan penambahan ampas teh. Karakteristik acne face mask dapat dilihat pada Tabel 3. Hasil analisis $\mathrm{pH}$ pada produk dengan perlakuan rasio bubur rumput laut terbaik dan tanpa rumput laut (kontrol) yaitu 7,19 dan 7,45. Hasil analisis $\mathrm{pH}$ produk sudah sesuai dengan standar yang ditetapkan SNI nomor 16-6070-1999, yaitu $\mathrm{pH}$ produk untuk kulit berkisar antara 4,5-8,0.

Kesesuaian $\mathrm{pH}$ kulit dengan $\mathrm{pH}$ sediaan produk kulit wajah dapat mempengaruhi penerimaan kulit terhadap sediaan tersebut. Suatu sediaan masker wajah dikatakan ideal jika sediaan tersebut tidak mengiritasi kulit wajah. Suatu sediaan masker wajah akan menyebabkan kulit bersisik jika sediaan tersebut memiliki $\mathrm{pH}$ terlalu basa, sebaliknya suatu sediaan akan menyebabkan kulit iritasi jika $\mathrm{pH}$ sediaan terlalu asam. Hasil ini sesuai dengan penelitian Faradiba et al.(2013) yang menyatakan bahwa $\mathrm{pH}$ fisiologi kulit berkisar antara 4,5-7,5.

Semakin besar daya sebar maka luas permukaan kulit wajah yang kontak dengan sediaan semakin luas, sehingga zat aktif yang diharapkan dapat memberikan pengaruh positif dapat terdistribusi secara merata (Pratama dan Zulkarnain 2015).

Hasil uji daya sebar menunjukkan bahwa diameter penyebaran produk dari rasio terbaik sebanyak $1 \mathrm{~g}$ setelah ditutupi kaca adalah 1,5 $\mathrm{cm}$. Setelah diberi beban $200 \mathrm{~g}$ diameter daya sebar bertambah menjadi $5 \mathrm{~cm}$. Diameter daya sebar untuk perlakuan kontrol setelah ditutupi kaca yaitu $1 \mathrm{~cm}$, setelah diberi beban $200 \mathrm{~g}$ meningkat menjadi $4 \mathrm{~cm}$. Persyaratan daya sebar untuk sediaan produk kulit yaitu 5-7 $\mathrm{cm}$. Hasil ini dapat dikatakan bahwa produk sudah memenuhi syarat daya sebar yang baik. Daya sebar yang baik menyebabkan absorpsi zat aktif produk ke kulit dapat berlangsung efektif (Wibowo et al. 2017).

Tabel 2 Total Fenol Bubur Sargassum sp. dan E. cottonii

Table 2 Total phenolic of Sargassum sp. and E. cottonii porridge

\begin{tabular}{ccc}
\hline Perlakuan/Treatment & $\begin{array}{c}\text { Total fenol }(\mathrm{mg} \mathrm{GAE} / \mathrm{g}) / \\
\text { Total phenolic }(\mathrm{mg} \mathrm{GAE} / \mathrm{g})\end{array}$ & $\begin{array}{c}\text { Diameter hambat }(\mathrm{mm}) / \\
\text { Inhibitory zone }(\mathrm{mm})\end{array}$ \\
\hline $1: 1$ & $853.50 \pm 3.54^{\mathrm{b}}$ & $3.24 \pm 0.00^{\mathrm{b}}$ \\
$1: 2$ & $626.00 \pm 0.00^{\mathrm{a}}$ & $2.75 \pm 0.01^{\mathrm{a}}$ \\
$2: 1$ & $971.00 \pm 0.00^{\mathrm{c}}$ & $3.62 \pm 0.04^{\mathrm{c}}$ \\
\hline
\end{tabular}

Tabel 3 Karakteristik acne face mask

Table 3 Characteristicsof acne face mask

\begin{tabular}{lcc}
\hline & \multicolumn{2}{c}{ Parameter/Parameter } \\
\cline { 2 - 3 } & Nilai $\mathrm{pH} / \mathrm{pH}$ valeu & Daya sebar $(\mathrm{cm}) /$ Spread $(\mathrm{cm})$ \\
\hline $\begin{array}{l}\text { Formula dengan rumput laut/ } \\
\text { Formulation with saeweed }\end{array}$ & $6.96 \pm 0.24$ & $5 \mathrm{~cm}$ \\
Formula tanpa rumput laut/ & $7.46 \pm 0.35$ & $4 \mathrm{~cm}$ \\
Formulation without saeweed & $4.5-8.0\left(^{*}\right)$ & $5-7 \mathrm{~cm}\left({ }^{* *}\right)$ \\
Persyaratan/ Reference &
\end{tabular}

Ket : $\left(^{*}\right)$ SNI $\left.1999{ }^{(*}\right)$ Garg et al. (2002) 


\section{Antibakteri}

Hasil dari uji aktivitas antibakteri produk ini adalah terbentuknya zona bening yang terlihat di sekeliling sumur berdiameter 0,6 $\mathrm{cm}$. Hasil pengukuran diameter zona hambat dapat dilihat pada Tabel 4 .

Tabel 4 menunjukkan bahwa perlakuan kombinasi rumput laut dan ampas teh memberikan hasil yang berbeda nyata terhadap aktivitas antibakteri yang dihasilkan $(\mathrm{P}<0,05)$. Produk masker wajah terbukti dapat menghambat pertumbuhan bakteri $P$. acnes dengan terbentuknya zona bening di sekeliling sumur. Diameter zona hambat kontrol negatif, basis masker, acne face mask pada $P$. acnes, acne face mask pada $S$. aureus dan kontrol positif secara berturut-turut yaitu $0 \mathrm{~mm}, 0 \mathrm{~mm}, 2,60 \mathrm{~mm}, 10,67 \mathrm{~mm}$ dan $34,21 \mathrm{~mm}$. Produk masker wajah memiliki tingkat penghambatan yang lebih besar pada bakteri S. aureus dibandingkan pada bakteri $P$. acnes. Kontrol positif yaitu klindamisin $20 \%$ memiliki aktivitas antibakteri yang dikategorikan sangat kuat.

Pembanding yang digunakan dalam uji antibakteri penelitian ini yaitu akuades steril sebagai kontrol negatif dan klindamisin sebagai kontrol positif. Kontrol negatif menunjukkan tidak terbentuknya zona bening di sekitar sumur. Hal ini menunjukkan bahwa akuades steril tidak memiliki aktivitas antibakteri karena tidak memberikan pengaruh terhadap pertumbuhan bakteri P. acnes. Kontrol positif menunjukkan terbentuknya zona hambat di sekeliling sumur, sehingga dapat dikatakan bahwa klindamisin memiliki aktivitas antibakteri yang mempengaruhi pertumbuhan bakteri. Klindamisin merupakan antibioktik yang umumnya digunakan untuk obat jerawat karena dapat menghambat inflamasi dan membunuh bakteri (Wahdaningsih et al. 2014).

\section{Sensori}

Analisis sensori merupakan metode ilmiah yang digunakan untuk mengukur atau menganalisis respon yang dirasakan dari suatu produk melalui indra manusia. Parameter yang diuji meliputi tampilan, warna, aroma, dan tekstur. Hasil uji statistik berdasarkan nilai ANOVA yang diperoleh jika $<0,05$ maka akan dilakukan uji lanjut. Nilai sensori produk dapat dilihat pada Tabel 5 .

Hasil uji Duncan menunjukkan bahwa nilai kesukaan tertinggi terhadap tampilan masker terdapat pada masker komersil dengan nilai rata-rata 4,17 yang berbeda nyata dengan masker yang ditambahkan bubur rumput laut dan tanpa penambahan bubur rumput laut. Hal ini diduga karena masker komersil memiliki tampilan yang halus, sedangkan dengan penambahan bubur rumput laut dan ampas teh, tampilan masker cenderung terlihat kasar.

Nilai kesukaan tertinggi terhadap warna terdapat pada masker komersil dengan ratarata 4,27 yang berbeda nyata dengan masker yang ditambahkan bubur rumput laut dan tanpa penambahan bubur rumput laut. $\mathrm{Hal}$ ini diduga karena masker komersil memiliki warna cenderung abu, berbeda dengan masker penambahan bubur rumput laut dan tanpa penambahan bubur rumput laut diberikan ampas teh, yang mengakibatkan warna masker menjadi cokelat kehitaman, sehingga cenderung kurang disukai oleh panelis.

Nilai kesukaan panelis tertinggi terhadap aroma ditunjukkan pada masker dengan

Tabel 4 Diameter daya hambat acne face mask

Table 4 Diameter inhibitory of acne face mask

\begin{tabular}{lc}
\hline \multicolumn{1}{c}{ Perlakuan/Treatment } & Rata-rata $(\mathrm{mm}) /$ Average $(\mathrm{mm})$ \\
\hline Kontrol negatif/ Negative control & $0.00 \pm 0.00^{\mathrm{a}}$ \\
Basis masker & $0.00 \pm 0.00^{\mathrm{a}}$ \\
Acne face mask (P.acnes) & $2.60 \pm 0.00^{\mathrm{b}}$ \\
Acne face mask (S. aureus) & $10.67 \pm 0.00^{\mathrm{c}}$ \\
Kontrol positif/ Positive control & $34.21 \pm 0.01^{\mathrm{d}}$ \\
\hline
\end{tabular}


Tabel 5 Sensori acne face mask

Table 5 Sensory of acne face mask

\begin{tabular}{lccc}
\hline $\begin{array}{c}\text { Parameter/ } \\
\text { Parameter }\end{array}$ & $\begin{array}{c}\text { Formula tanpa rumput } \\
\text { laut/ Formulation with } \\
\text { seaweed }\end{array}$ & $\begin{array}{c}\text { Formula dengan rumput } \\
\text { laut/ Formulation without } \\
\text { seaweed }\end{array}$ & $\begin{array}{c}\text { Komersial/ } \\
\text { Commercial }\end{array}$ \\
\hline Tampilan/Appearance & $3.2^{\mathrm{a}}$ & $3.5^{\mathrm{ab}}$ & $4.17^{\mathrm{c}}$ \\
Warna/Color & $2.93^{\mathrm{a}}$ & $3.33^{\mathrm{ab}}$ & $4.27^{\mathrm{c}}$ \\
Aroma/Scent & $3.47^{\mathrm{ab}}$ & $3.7^{\mathrm{a}}$ & $3.67^{\mathrm{c}}$ \\
Tekstur/Texture & 3.53 & 3.53 & 4.17 \\
\hline
\end{tabular}

penambahan bubur rumput laut dengan rata-rata 3,7 yang berbeda nyata dengan masker tanpa penambahan bubur rumput laut dan masker komersil. Hal ini diduga karena kombinasi bubur rumput laut dan ampas teh pada masker menghasilkan aroma alami, berbeda dengan masker perlakuan lainnya. Tekstur yang dihasilkan dari ketiga masker tidak memberikan pengaruh nyata. Hal ini diduga karena ketiga masker memiliki kesamaan tektur yaitu kasar.

\section{KESIMPULAN}

Hasil penelitian menunjukkan bahwa rasio terbaik bahan baku bubur rumput laut untuk pembuatan produk masker wajah yaitu Sargassum sp. : E. cottonii (2:1). Bubur rumput laut mengandung senyawa alkaloid, flavonoid, fenol, dan saponin, dengan fenol 50,43 mg GAE/g, dan aktivitas antioksidan 145,89 $\pm 0,42$ ppm, daya hambat $3,62 \pm 0,04 \mathrm{~mm}$. Ampas teh memiliki kemampuan menghambat $P$. acnes sebesar $2,44 \mathrm{~mm}$ dan $S$. aureus sebesar 8,56 $\mathrm{mm}$. Acne face mask yang dihasilkan memiliki diameter daya hambat terhadap $P$. acnes yaitu $2,60 \pm 0,00 \mathrm{~mm}$ dan terhadap $S$. aureus yaitu $10,67 \pm 0.00 \mathrm{~mm}$.

\section{DAFTAR PUSTAKA}

[AOAC] Association of Official Analitycal Chemist. 1995. Official Method of analysis. Marylandn: Association of Official Analytical Chemist, Inc.

[AOAC] Association of Official Analitycal Chemist. 2005. Official Method of Analysis of The Association of Official Analytical of Chemist. Arlington, Virginia, USA: Association of Official Analytical Chemist, Inc.
Achroni, Keen. 2012. Seтua Rahasia Kulit Cantik dan Sehat Ada di sini. Yogyakarta (ID): Javalitera.

[BPOM] Badan Pengawas Obat dan Makanan. 2016. Penertiban kosmetika impor ilegal dan kosmetika mengandung bahan berbahaya. Jakarta (ID): BPOM.

[BSN] Badan Standarisasi Nasional. 1992. Pengukuran Kadar Air (SNI 01-28911992, Butir 5.1). Jakarta (ID): Badan Standarisasi Nasional

[BSN] Badan Standarisasi Nasional. 1999. 166070-1999. Sediaan Masker. Jakarta (ID): Badan Standarisasi Nasional.

Carolia N, Noventi W. 2016. Potensi Ekstrak Daun Sirih Hijau (Piper betle L.) sebagai Alternatif Terapi Acne vulgaris. Jurnal Majority. 5(1): 140-145.

Diachanty S, Nurjanah, Abdullah A. 2017. Aktivitas antioksidan berbagai jenis rumput laut cokelat dari perairan kepulauan seribu. Jurnal Pengolahan Hasil Perikanan Indonesia. 20(2): 305-318.

Dolorosa MT, Nurjanahm Puwaningsih S, Anwar E, Hidayat T. 2017. Kandungan senyawa bioaktif bubur rumput laut Sargassum plagyophyllum dan E. cottonii sebagai bahan baku krim pencerah kulit. Jurnal Pengolahan Hasil Perikanan Indonesia. 20(3): 633-644.

Fachrozan R. 2017. Karakterisasi bubur rumput laut Sargassum sp. dan Eucheuma cottonii sebagai bahan baku sediaan Lipbalm [Skripsi]. Bogor (ID): Departemen Teknologi Hasil Perairan, Fakultas Perikanan dan Ilmu Kelautan, Institut Pertanian Bogor. 
Faradiba, Attamimi F, Maulida R. 2013. Formulasi krim wajah dari sari buah jeruk lemon dan anggur dengan variasi konsentrasi emulgator. Majalah Farmasi dan Farmakologi. 17(1): 17-20.

Garg A, Aggarwal D, Garg S, Sigla AK. 2002. Spreading of Semisolid Formulation: An Update. Pharmaceutical Technology. 84-102.

Hamsinah, Darijanti SD, Mauluddin R. 2016. Uji stabilitas formulasi krim tabir surya serbuk rumput laut (E. cottonii). Jurnal Fitofarmaka Indonesia. 3(2): 155-158.

Ihsan F. 2016. Pembuatan nori dengan pemanfaatan kolang-kaling sebagai bahan substitusi rumput rumput laut jenis E. cottonii. Padang (ID): Universitas Andalas.

Jawetz M, Adelberg's. 2005. Mikrobiologi Kedokteran. Penerjemah: N. Widorini. Jakarta (ID): Penerbit Salemba Medika.

Jones RM. 2014. ABC of Dermatology. London (UK) : BMJ Books.

Kartheepan K, Suhail A, Mithuna V, Prianka L. 2015. Evaluation of common risk factors of acne in teenagers in Batticaloa district. $5^{\text {th }}$ International Symposium. 168-171.

Kosasih EN, Setiabudhi T, Heryanto $H$. 2004. Peranan antioksidan pada lanjut usia. Jakarta (ID): Pusat Kajian Nasional Masalah Lanjut Usia.

Kusumaningrum R, Supriadi A, Hanggita S. 2013. Karakteristik dan mutu teh bunga lotus. Jurnal Fishtech. 2(1): 9-21.

Luthfiyana N, Nurjanah, Nurilmala $M$, Anwar E, Hidayat T. 2016. Rasio bubur rumput laut E. cottonii dan Sargassum sp. sebagai formula krim tabir surya. Jurnal Pengolahan Hasil Perikanan Indonesia. 19(3): 183-195.

Maharany F, Suwandi R, Anwar E, Hidayat T. 2017. Kandungan senyawa bioaktif bubur rumput laut Padina australis dan E. cottonii sebagai bahan baku krim pencerah kulit. Jurnal Pengolahan Hasil Perikanan Indonesia. 20(1): 10-17.

Marselia S, Wibowo MA, Arreneuz S. 2015. Aktivitas antibakteri ekstrak daun soma terhadap Propionibacterium acnes. Jurnal Kimia Khatulistiwa. 4(4): 72-82.
Melayanti PC, Dwiyanti S. 2017. Pengaruh persentase umpi rumput teki dan tepung beras terhadap kulit wajah hiperpigmentasi. e-Journal. 6(1): 89-98.

Molyneux P. 2004. The use of stable free radical diphenylpicrylhydrazyl (DPPH) for estimating antioksidan activity. Songklanakarin Journal Science Tech. 26(2): 211-219.

Nawaly H, Uktolseja J, Susanto AB. 2013. Senyawa bioaktif dari rumput laut sebagai antioksidan. Seminar Nasional X Pendidikan Biologi FKIP UNS.

Nurjanah, Abdullah A, Nufus C. 2018. Karakteristik sediaan garam Ulva lactuca dari Perairan Sekotong Nusatenggara Barat bagi pasien hipertensi. Jurnal Pengolahan Hasil Perikanan Indonesia. 20(3): 109-117.

Nurjanah, Jacoeb MJ, Hidayat T, Chrystiawan R. 2018. Perubahan komponen serat rumput laut Caulerpa sp. (dari Tual, Maluku) akibat proses perebusan. Jurnal Ilmu dan Teknologi Kelautan. 10(1): 35-48.

Nurjanah, Anwar E, Yanuarti R. 2017. Karakteristik sediaan krim tabir surya menggunakan kombinasi bubur rumput laut Turbinaria ornata dan Euchema cottonii. Prseding SeminarPPIS BSN. 250-260

Nurjanah, Nurilmala M, Anwar E, Luthfiyana $\mathrm{N}$, Hidayat T. 2017. Identification of bioactive compounds of seaweed Sargassum sp. and Eucheuma cottonii doty as a raw sunscreen cream. Proceedings of the Pakistan Academy of Sciences: B. Life and Environmental Sciences. 54(4): 311-318.

Nurjanah, Nurilmala N, Sudiarjo F, Hidayat T. 2016. Characteristics of seaweed as raw materials for cosmetics. Aquatic Procedia. 7: 177 - 180 .

Pangestuti IE, Sumardianto, Amalia U. 2017. Skrining senyawa fitokimia rumput laut Sargassum sp. dan aktivitasnya sebagai antibakteri terhadap Staphylococcus aureus dan Escherichia coli. Saintek Perikanan. 12(2): 98-102. 
Pangihutan PE, Yetti H, Isnaini. 2017. Pengaruh pemberian ampas teh dan pupuk NPK terhadap pertumbuhan bibit tanaman kopi arabika. Jurnal Online Mahasiswa Fakultas Pertanian. 4(2): 1-11.

Pebrianata E. 2005. Pengaruh pencampuran kappa dan iota karaginan terhadap kekuatan gel dan viskositas karaginan campuran. [Skripsi]. Bogor (ID): Fakultas Perikanan Dan Ilmu Kelautan, Institut Pertanian Bogor.

Picardo M, Ottaviani M, Camra E, Mastrofancesco A. 2009. Sebaceous gland lipids. Dermato Endocinology. 1(2): 68-71.

Pratama WA, Zulkarnain AK. 2015. Uji SPF in vitro dan sifat fisik beberapa produk tabir surya yang berebdar di pasaran. Majalah Farmaseutik. 11(1): 275-283.

Putra DAP, Agustini TW, Wijayanti I. 2015. Pengaruh penambahan karagenan sebagai stabilizer terhadap karakteristik otak-otak ikan kurisi (Nemipterus nematophorus). Jurnal Pengolahan dan Bioteknologi Hasil Perikanan. 4(2): 1-10.

Rahmi A, Cahyanto T, Sujarwo T, Lestari RI. 2015. Uji aktivitas antibakteri ekstrak daun beluntas terhadap Propionibacterium acnes penyebab jerawat. Jurnal Istek. 9(1): 141-161.

Ramamoorthy, P and Bono, A., 2007, Antioxidant Activity, Total Phenolic and Flavonoid Content of Morinda citrifolia Fruit Extracts from Various Extraction Processes. Journal of Engineering Science and Technology. 2(1): 70- 80.

Ramdani R, Sibero HT. 2015. Treatment for acne vulgaris. J Majority. 4(2): 87-95.

Sartika R, Melki, Purwiyanto IS. 2013. Aktivitas antibakteri ekstrak rumput laut Eucheuma cottoni terhadap bakteri
Escherichia coli, Staphylococcus aureus, Vibrio cholera dan Salmonella typhosa. Maspari Journal. 5(2): 98-103.

Sedjati S, Suryono, Santosa A, Supriyantini E, Ridlo A. 2017. Aktivitas antioksidan dan kandungan senyawa fenolik makroalga cokelat Sargassum sp. Jurnal Kelautan Tropis. 20(2): 117-123.

Vilar GN, Filho JFS, Santos LA. 2015. Quality of Life, Self-esteem and psychosocial factors in Adolescents with Acne Vulgaris. An Bras Dermatol. 90(5): 622-629.

Wahdaningsih S, Untari EK, Fauziah Y. 2014. Antibakteri fraksi n-Heksana kulit Hylocereus polyrhizus terhadap Staphylococcus epidermidis dan Propionibacterium acnes. Pharmaceutical Science Research. 1(3): 180-193.

Wibowo SA, Budiman A, Hartanti D. 2017. Formulasi dan aktivitas anti jamur sediaan krim M/A ekstrak etanol buah takokak terhadap Candida albicans. Jurnal Riset Sains dan Teknologi. 1(1): 15-21.

Wibowo YS, Riyanto J, Subagyo YBP. 2014. Pengaruh penggunaan ampas teh (Camellia sinensis) dalam ransum terhadap produksi karkas kelinci New Zealand White jantan. Jurnal Biofarmasi. 12(1): 11-17.

Widiati S. 2011. Daya hambat ekstrak ampas teh hitam (Camellia sinensis) terhadap pertumbuhan Staphylococcus epidermidis [Skripsi]. Yogyakarta (ID): Fakultas Teknobiologi, Universitas Atmajaya Yogyakarta.

Yanuarti R, Nurjanah, Anwar E, Hidayat T. 2017. Profil fenolik dan aktivitas antioksidan dari ekstrak rumput laut Turbinaria conoides dan E. cottonii. Jurnal Pengolahan Hasil Perikanan Indonesia. 20(2): 230-237. 